\title{
Efficacy of Some Fungicides, Commercial Plant Oils and Bio-Agents against Drechslera Graminea Inciting Barley Leaf Stripe Disease
}

\author{
*Amira M.A. Mahmoud, **Nawal A. Eisa, **Gehad M. El-Habbaa, *Faten Kamel El-Nashar, **Ibrahim \\ A.I. EL-Fiki, \\ * Plant Pathol. Res. Inst., Agric. Res. Center, Giza, Egypt. \\ ** Plant Pathol. Dept., Fac. Agric., Benha Univ., Egypt. \\ Corresponding author: ibrahim.elfiki@ fagr.bu.edu.eg, $\underline{\text { ibrahimelfiki76@gmail.com }}$
}

\begin{abstract}
The antifungal activity of 5 fungicides, 3 commercial plant oils and 2 bio-agents were tested in vitro and in vivo against Drechslera graminea (Rabenh. ex. Schlech) Shoemaker (telemorph: Pyrenophora graminea Ito and Kuribayashi, the causal organism of leaf stripe disease on barley (Hordeum vulgare L.). Among fungicides tested, Opus at $1 \mu \mathrm{l} / \mathrm{L}$ and Switch at $1 \mathrm{mg} / \mathrm{L}$ concentration and Bellis at $2 \mathrm{mg} / \mathrm{L}$ showed $100 \%$ mycelia growth inhibition of D. graminea. The results of commercial plant oils tested in vitro revealed that the coriander showed highest inhibition of mycelial growth at $15 \%$. The dual culture technique revealed that fungal bio-agent (Trichoderma harzianum) was better than bacterial bio-agent (Bacillus subtilis) in inhibiting the growth of D. graminea.

Greenhouse and field experiments were carried out to evaluate the efficacy of all tested treatments on disease incidence, yield components, enzymes activity and phenolic compounds. The tested fungicides, plant oils and bioagents applied as seed dressing showed an effectiveness to large extent for controlling leaf stripe disease expressed as a reduction in disease incidence and increased yield components in comparing with the untreated plants. As well as, the all treatments caused an increment in activities of peroxidaxe, polyphenol oxidase and chitinase enzymes and increasing in phenolic compounds compared to control treatment. Although the five tested fungicides were more effective in reducing the linear growth of the pathogen $(D$. graminea) in vitro and suppressing the disease in vivo than the plant oils and bio-agents, they are considered environmentally safe and can be used as alternative substances in disease management.
\end{abstract}

Keywords: Drechslera graminea - barley - fungicides - plant oils - bio-agents - yield - total phenols - plant defense-related enzymes.

\section{Introduction}

Barley, (Hordeum vulgare L.), belongs to family gramineae, is known as one of the most economically important cereal grain crop worldwide, widely grown in the semi-arid regions. In Egypt, barley mainly grown in a large scale in the north coastal region, in the newly reclaimed saline lands and areas with shortage of fresh water, barley ranks fourth globally among cereal crops and the fourth ranking cereal in Egypt after wheat, maize and rice (Noaman, 2008). Total harvested areas in Egypt from 2016/2017 season amounted to 175,270 feddan with an annual production of approximately 239 , 6667 ton (Economic Affairs Sector- Bulletin of Agriculture Statistics 2016/2017). Barley plants are infected with many fungal pathogens. The leaf stripe disease caused by Drechslera graminea; a serious seedborne fungus, is the most common destructive disease of barley that can cause significant economic yield losses (Zare and Hashemi, 2013). The importance of such disease is returned to that infection could be in form of; plants without ears, plants with ears but without grains and plants with ears with deformed grains (Kavak, 2004). In addition, if infected seed is resown without an effective controlling treatment being applied, the disease could multiply very expressively and produce large economic yield losses (Zare and Hashemi, 2013). For controlling leaf stripe disease of barley, several management strategies were done to manage such disease, such as using resistant cultivars, crop rotation, tillage and fungicides application (Pecchioni et al., 1999). Among the most truly effective and old method for disease control is using of fungicides. Recently, using of non-chemical treatments against seed borne pathogens has been given much attention. In this respect, plant extracts have played significant inhibitory effects on plant pathogens and improved seed quality (Nwachukwu and Umechuruba, 2001). Also, the essential oils and their constituents have been found effective as antifungal agent (Daferera et al., 2000; Sridhar et al., 2003). In view of harmful impact of fungicides and pestsides and other agrochemicals on the ecosystem, the bio-control of plant disease as an alternate strategy has attracted the interest (Lockwood, 1988). Biological control for soilborne pathogens by antagonistic microorganisms is potential especially for soil-borne diseases because these pathogens are difficult to be controlled with specific pesticides (Moussa et al., 2007). In this respect, several bacterial and fungal agents showing disease suppressing abilities have also been extensively studied (Hornby, 1990). Several research workers indicated that changes in peroxidase, polyphenol oxidase and phenolic compounds were found to be affected by pathogen infected as well as the interaction between the pathogen and the compounds used to control the disease (Yedidia et al., 2003; Velazhahan and Vidhyasekaran, 1994). 
The present investigation was carried out to evaluate the efficiency of some fungicides, plant oils and bio-agents against $D$. graminea fungus, the causal organism of barley leaf stripe disease in vitro and in vivo under greenhouse and field conditions, as well as their effectiveness on yield parameters, phenolic compounds and enzymes activities.

\section{Materials and Methods}

\section{Isolation and identification of the causal pathogen:}

Isolation of the causal pathogen of barley leaf stripe disease was done from naturally infected barley plants which showed typical symptoms of barley leaf stripe disease and cultivated in ELBehaira governorate during growing season 2013/2014 and subjected to isolation trails. In this respect, infected leaves with advanced margins of leaf stripe lesions were picked and cut into small bits with about $5 \mathrm{~mm}$ for isolation and purification of the causal fungus according to Naik et al., (2010). The isolated target fungus was purified using hyphal tip technique (Brown, 1924) and identified on the basis of cultural and microscopic morphological characteristics and pigmentation on medium and mycelial growth patter non PDA plates according to (Ito, 1930) where the macroscopic characters (color, sector, border and texture) of each colony were recorded at 24-hour interval until one of the colonies had reached the border of the plate. Pathogenicity test and Koch's postulates were carried out successfully on barley seedlings (cv. Giza 123) under greenhouse conditions at Plant Pathology Institute, Agricultural Research Center (ARC), Giza, to confirm its pathogenicity and re-isolated pure cultures of $D$. graminea was maintained on PDA slants at $4^{\circ} \mathrm{C}$.

\section{Effect of some tested treatments on $D$. graminea growth in vitro:}

\subsection{Effect of some fungicides:}

The fungicidal activities of five commercial fungicides illustrated in Table $\mathbf{1}$ were screened against the targeted $D$. graminea fungus isolate in vitro. Eight concentrations were tested for each fungicide i.e. 0.0, 0.1, 0.2, 0.4, 0.6, 0.8 and 1, 2 for the three fungicides i.e. Opus $12.5 \% \mathrm{SC}(\mu \mathrm{l} / \mathrm{L})$, Bellis $38 \% \mathrm{WG}(\mathrm{mg} / \mathrm{L})$ and Switch 62.5\%WG (mg/L), while Collis $30 \% \mathrm{SC}$ and Uniform $39 \% \mathrm{SC}$ were tested at concentrations $0.0,1,2,4,6,8,10$ and 12 $(\mu 1 / \mathrm{L})$.

Table 1. Trade name, active ingredient, chemical formula and recommended doses of tested fungicides for controlling D. graminea fungus, the causal of barley leaf stripe disease in vitro:

\begin{tabular}{|c|c|c|c|}
\hline $\begin{array}{c}\text { Trade name } \& \\
\text { producer }\end{array}$ & $\begin{array}{c}\text { Active } \\
\text { ingredient }\end{array}$ & Chemical name & $\begin{array}{l}\text { Recommended } \\
\text { dose }\end{array}$ \\
\hline $\begin{array}{c}\text { Opus } 12.5 \% \text { SC*, } \\
\text { BASF Co. }\end{array}$ & Epoxiconazole & $\begin{array}{l}\text { 1-\{[3-(2-chlorophenyl)-2-(4- } \\
\text { fluorophenyl)oxiran-2-yl]methyl }\}-1 \mathrm{H}-1,2,4- \\
\text { triazole }\end{array}$ & $2.0 \mathrm{ml} / \mathrm{kg}$ \\
\hline $\begin{array}{c}\text { Bellis 38\% WG*, } \\
\text { BASF Co. }\end{array}$ & $\begin{array}{c}\text { Pyrachlostrobin } \\
+ \\
\text { Boscalid }\end{array}$ & $\begin{array}{l}\text { Pyrachlostrobin: } \\
\text { Methyl (2-(((1-(4-chlorophenyl)-1H-pyrazol-3- } \\
\text { yl)oxy)methyl)phenyl)(methoxy)carbamate. } \\
\text { Boscalid: } \\
\text { Methyl (2-(((1-(4-chlorophenyl)-1H-pyrazol-3- } \\
\text { yl)oxy)methyl)phenyl)(methoxy)carbamate. } \\
\text { Cyprodinil: }\end{array}$ & $0.5 \mathrm{~g} / \mathrm{kg}$ \\
\hline $\begin{array}{c}\text { Switch 62.5\% WG, } \\
\text { Syngenta Co. }\end{array}$ & $\begin{array}{l}\text { Cyprodinil } \\
\qquad+ \\
\text { Fludioxonil }\end{array}$ & $\begin{array}{l}\text { 4-cyclopropyl-6-methyl- } N \text {-phenylpyrimidin-2- } \\
\text { amine. } \\
\text { Fludioxonil: } \\
\text { 4-(2,2-difluoro-1,3-benzodioxol-4-yl)- } 1 H \text { - } \\
\text { pyrrole-3-carbonitrile. } \\
\text { Boscalid: }\end{array}$ & $1.0 \mathrm{~g} / \mathrm{kg}$ \\
\hline $\begin{array}{c}\text { Collis } 30 \% \mathrm{SC} \text {, BASF } \\
\text { Co. }\end{array}$ & $\begin{array}{l}\text { Boscalid } \\
\quad+ \\
\text { Kreoxim- } \\
\text { methyl }\end{array}$ & $\begin{array}{l}\text { Methyl (2-(((1-(4-chlorophenyl)-1H-pyrazol-3- } \\
\text { yl)oxy)methyl)phenyl)(methoxy)carbamate. } \\
\text { Kreoxim-methyl: } \\
\text { methyl (2E)-2-methoxyimino-2-[2-[(2- } \\
\text { methylphenoxy)methyl]phenyl]acetate. } \\
\text { Azoxestrobin: }\end{array}$ & $0.5 \mathrm{ml} / \mathrm{kg}$ \\
\hline $\begin{array}{c}\text { Uniform } 39 \% \text { SC, } \\
\text { Syngenta Co. }\end{array}$ & $\begin{array}{c}\text { Azoxystrobin } \\
+ \\
\text { Mefenoxam }\end{array}$ & $\begin{array}{l}\text { Methyl } \quad(2 \mathrm{E})-2-(2-\{[6-(2- \\
\text { cyanophenoxy)pyrimidin-4-yl]oxy }\} \text { phenyl)-3- } \\
\text { methoxyacrylate. } \\
\text { Mefenoxam: } \\
\begin{array}{l}\text { methyl } \\
\text { dimethylanilino)propanoate. }\end{array}\end{array}$ & $1.0 \mathrm{ml} / \mathrm{kg}$ \\
\hline
\end{tabular}

$* \mathrm{SC}=$ suspension concentrate $* \mathrm{WG}=$ water dispersible granules 
During this experiment, agar dilution method was used on PDA medium according to the method of Robert et al., (1996). The Non-amended PDA plates served as a control. Mycelial plug (5mm) from 7-day old cultures were placed at the center of PDA plates. All plates were incubated at $22 \pm 2^{\circ} \mathrm{C}$ until the colony of the control plate was completely filled the plate, then the inhibition index percentage (IP\%) was calculated as the following using the formula suggested by Skidmore and Dickenson, (1976) as follows: IP\% $=((\mathbf{C}-\mathbf{T}) / \mathbf{C}) * \mathbf{1 0 0}$ where, IP\% $=$ inhibition index percentage over control, $\mathrm{C}=$ radius growth of control $(\mathrm{mm}), \mathrm{T}=$ radius growth of treatment $(\mathrm{mm})$. Also, the half maximal inhibitory concentration $\left(\mathrm{IC}_{50}\right)$; the concentration giving $50 \%$ linear growth inhibition, was calculated using EPA PROBIT analysis program version 1.5. As well as, $\mathrm{MIC}_{90}$; the minimum inhibition concentration which inhibits the linear growth of D. graminea over $90 \%$ was calculated.

\subsection{Effect of some commercial plant oils:}

The antifungal activities of three commercial plant oils i.e. coriander (Coriandrum sativus), marjoram (Origanum majorana) and caraway (Carum carvi) oils obtained from EL Captain Company for Extracting Natural Oils and Plants; were evaluated against the targeted D. graminea isolate in vitro. Nine concentrations were tested for each tested plant oil, i.e. $0.0,4,5,6,7,8,9,10,15 \%$. During this experiment, poisoned food technique was used on PDA medium according to the modified method of Nene and Thapliyal, (1993).The IP\%, $\mathrm{IC}_{50}$ and $\mathrm{MIC}_{90}$ of tested commercial plant oils were calculated as mentioned before.

\subsection{Effect of some bio-agents:}

Two bio-agents, i.e. Trichoderma harzianum and Bacillus subtilis "kindly obtained from the Central Lab of Organic Agriculture, ARC, Giza, Egypt" were screened against the targeted $D$. graminea isolate in vitro. Dual culture technique was used for in vitro evaluation of the two tested antagonistics. Potato dextrose agar (PDA) medium was used in this experiment. The antifungal activity of tested treatments accomplished on PDA plates $(90$ $\mathrm{mm} \varnothing)$. Concerning to $T$. harzianum treatment, aseptically, a PDA disc inoculum $(5 \mathrm{~mm})$ of young active culture of $T$. harzianum was placed on PDA plates at a distance of $20 \mathrm{~mm}$ from the plate margin. At the opposite direction, at distance of $20 \mathrm{~mm}$ from the plate margin, PDA disc inoculums $(5 \mathrm{~mm})$ of young active culture of $D$. graminea was placed on. Concerning to $B$. subtilis bio-agent treatment, by a similar way, single streaks technique according to Wang et al., (2003) with some modifications was used, where, single streak of $B$. subtilis bacterium was drawn by a loop at a distance of $20 \mathrm{~mm}$ from the margin of the plate, and then, the plates were incubated for $24 \mathrm{~h}$ (this time is enough for the colonies to be visible) at $27^{\circ} \mathrm{C}$. At the opposite direction of Bacillus streak, an equal disc inoculum (5 $\mathrm{mm} \emptyset$ ) of young active culture of D. graminea was placed on at distance of $20 \mathrm{~mm}$ from the margin of the plate. Plates containing D. graminea inoculum disc only on the center of the plate represented as control treatment. The inoculated plates were incubated at $22 \pm 2^{\circ} \mathrm{C}$ and daily observed until the radius growth of $D$. graminea inoculum covered whole plate in control. The IP\% of tested bio-agents was calculated as mentioned before at 2, 3, 4 and 7 days post inoculation.

\section{Control of barley leaf stripe disease:}

The current study was conducted out during the winter growing season 2016/2017 under both greenhouse condition "at the Plant Pathology Institute, Agricultural Research Center (ARC), Giza" and open field condition in two locations "at the Experimental Station, ARC, Giza governorate, and Kafr-Elhmam Station, ARC, El-Sharquia governorate". This experiment was carried out on barley grains (cv.Giza123) naturally infected with barley leaf stripe.

\subsection{Greenhouse experiment:}

The fungicidal activities of the five abovementioned commercial fungicides i.e. Opus $12.5 \% \mathrm{SC}$, Bellis $38 \% \mathrm{WG}$, Switch $62.5 \% \mathrm{WG}$, Collis $30 \%$ SC and Uniform $39 \%$ SC were screened against the barley leaf stripe disease caused by $D$. graminea under greenhouse condition. Three concentrations were tested for each fungicide i.e. half recommended; recommended and double recommended dose $/ \mathrm{kg}$ barley grain. Concerning the tested commercial plant oils, the tested treatments of coriander, marjoram and caraway oils which have inhibitory effects on the barley leaf strip pathogen (D. graminea) in vitro tests ex. 9, 10 and $15 \%$ for each tested plant oil; were subjected as well as to in vivo test under greenhouse condition to determine their control efficacy against barley leaf strip disease. As for bio-agent treatments, i.e. T. harzianum and $B$. subtilis were prepared at $30 \times 10^{6} \mathrm{CFU} / \mathrm{mL}$ for each antagonistic. Application of each prepared antagonistic was applied at the rate of $1 / 100 \mathrm{~L}$ water, $1 / 75 \mathrm{~L}$ water and $1 / 50 \mathrm{~L}$ water individually to determine their effects in controlling barley leaf stripe disease on barley plants. Treatments were applied individually using barley grains cv. Giza 123 naturally infected with barley leaf strip disease. Treatments were applied as grain soaking for 20 minutes for each tested treatment and then left to air dry before sowing. Grains soaked in sterilized distilled water served as control treatment. All treatments were sown in pottery pots $(30 \mathrm{~cm} \varnothing)$ filled with unsterilized clay soil $(3 \mathrm{~kg} / \mathrm{pot})$ each containing 12 grains, under greenhouse conditions. The experiment was done in complete randomized block 
design with three replicates. Disease incidence was recorded at GS61; the growth stage which flowering of barley plants is beginning (Zadocks et al., 1974), as percentage of infected plants comparing with the total number of plants.

\subsection{Open field experiment:}

The present experiment was carried out on barley grains (cv. Giza 123) naturally infected with barley leaf stripe disease under open field conditions at the Experimental Station, Agriculture Research Centre, Giza, and at Kafr-Elhmam Station, Agriculture Research Centre, El-Sharquia governorate during the successive winter growing season 2016/2017. The applied treatments of tested fungicides were applied at their recommended dose for each, while the applied treatments of the tested commercial plant oils and bio-agents were chosen on the base of the best concentration that gave least disease incidence percentage under the previously above-mentioned greenhouse experiment. The experimental treatments were laid out in randomized complete block design with three replicates (plots). Each experimental plot included 5 ridges, each of 1.5 $\mathrm{cm}$ wide and $2 \mathrm{~m}$ long. Plot area was $3 \mathrm{~m}^{2}$. On the $1^{\text {st }}$ of December, sowing of treated barley grains Giza $123 \mathrm{cv}$. took place in two sides of the ridge in the absence of water, each plot contained 250 plants. All agronomic practices endorsed by Ministry of Agriculture, Egypt were carried out for cultivation of barley plants, except fungicide application practices. Disease incidence was recorded as mentioned before in greenhouse experiments.

\section{Disease assessments and yield parameters:}

At 70-days after sowing (Growth Stage 61 "GS61"; flowering beginning of barley plant), disease incidence percentage was recorded. As well as, at maturity stage, plant height $(\mathrm{cm})$, grain number/spike, grain weigh/spike $(\mathrm{g})$ and thousand kernel weight $(\mathrm{g})$ were recorded for each treatment. Disease incidence (DI\%) was calculated and expressed in percentage scale by using the following formula: DI\% $=(\mathrm{D} / \mathrm{T}) \times 100$, where, $(\mathrm{I})=$ Number of diseased plants; $(\mathrm{T})=$ Total observed plants. Efficacy percentage (Ef\%) of different treatments was calculated based on mean of disease incidence percentage. Efficacy\% (Ef\%) calculated for comparison all tested treatments with untreated control (Mahmoud et al., 2013) as follows: $=\left(\begin{array}{l}\text { Ef } \% \\ \frac{\text {-disease incidence } \% \text { in control treatment }}{\text { disease incidence } \% \text { in control treatment }}\end{array}\right) \times 100$

5. Biochemical change assessments:

At 45-days post emergence of treated barley grains, samples representing the whole plant leaves were taken from each particular treatment for determining of total phenols contents, activities of some plant defense-related enzymes ex. polyphenole oxidase, peroxidase and chitinase, in treated barley plants. For total phenol contents determination, leaves samples were extracted separately by using the method suggested by Simons and Ross (1971). The total phenol contents in extracts was determined by Folin - Ciocateu methodas modified by Bary and Thorpe (1954), and were calculated for each treatment as milligrams of catechol per one gram dry weight (mg cat/g DW) according to standard curve of catechol. The crude leaf enzyme extract was prepared as recommended by Anand $\boldsymbol{e t}$ al., (2007). The activity of peroxidase enzyme (PO) was measured as described by Allam and Hollis (1972), and was calculated for each treatment as the change in absorbance at $425 \mathrm{~nm}$ per $15 \mathrm{~min}$ per gram fresh weight $\left(\Delta_{425} / 15 \mathrm{~min} / \mathrm{g} \quad \mathrm{FW}\right)$. Polyphenoloxidase activity (PPO) was determined according to Matta and Dimond (1963), and was calculated as $\left(\Delta_{420} / 30\right.$ $\mathrm{min} / \mathrm{g} \mathrm{FW}$ ). Chitinase activity was determined by the method of Boller and Mauch, (1988), and was expressed as $\mathrm{mM} \mathrm{N}$-acetyl glucoseamine equivalent per gram fresh weight per $60 \mathrm{~min}$.

\section{Statistical analyses:}

Statistical analyses of all the previously designed experiments have been carried out according to the procedures (ANOVA) reported by Snedecor and Cochran (1989). Treatment means were compared by the least significant difference test "LSD" at 5\% level of probability.

\section{Results and Discussion}

\section{Effect of some tested treatments on $D$.} graminea growth in vitro:

\subsection{Effect of fungicides:}

Five different fungicides were tested against $D$. graminea for their fungicidal properties on radius growth. Results in Table (2) reveal that, all treatments significantly reduced the radius growth of $D$. graminea in comparing with control. It well noticed that inhibition\% increased by increasing the fungicide 
Table 2. Effect of some tested fungicides on D. graminea fungus 7 days post incubation at $22 \pm 2^{\circ} \mathrm{c}$ in vitro:

\begin{tabular}{|c|c|c|c|c|c|}
\hline Treatment & Concentration & $\begin{array}{c}\text { Linear growth } \\
(\mathbf{m m})\end{array}$ & $\begin{array}{c}\text { Inhibition } \\
\%\end{array}$ & IC $_{50}$ & $\mathrm{MIC}_{90}$ \\
\hline \multirow{7}{*}{ Opus $12.5 \%$ SC } & $0.1 \mu \mathrm{l} / \mathrm{L}$ & 46.67 & 48.10 & \multirow{7}{*}{$0.127 \mu \mathrm{l} / \mathrm{L}$} & \multirow{7}{*}{$0.8 \mu \mathrm{l} / \mathrm{L}$} \\
\hline & $0.2 \mu 1 / \mathrm{L}$ & 33.67 & 62.60 & & \\
\hline & $0.4 \mu 1 / \mathrm{L}$ & 20.67 & 77.00 & & \\
\hline & $0.6 \mu \mathrm{l} / \mathrm{L}$ & 9.00 & 87.44 & & \\
\hline & $0.8 \mu \mathrm{l} / \mathrm{L}$ & 2.83 & 95.20 & & \\
\hline & $1.0 \mu \mathrm{l} / \mathrm{L}$ & 0.00 & 100.00 & & \\
\hline & $2.0 \mu 1 / \mathrm{L}$ & 0.00 & 100.00 & & \\
\hline \multirow{7}{*}{ Switch 62.5\%WG } & $0.1 \mathrm{mg} / \mathrm{L}$ & 73.33 & 29.70 & \multirow{7}{*}{$0.230 \mathrm{mg} / \mathrm{L}$} & \multirow{7}{*}{$0.8 \mathrm{mg} / \mathrm{L}$} \\
\hline & $0.2 \mathrm{mg} / \mathrm{L}$ & 49.00 & 45.60 & & \\
\hline & $0.4 \mathrm{mg} / \mathrm{L}$ & 36.67 & 59.20 & & \\
\hline & $0.6 \mathrm{mg} / \mathrm{L}$ & 31.00 & 65.60 & & \\
\hline & $0.8 \mathrm{mg} / \mathrm{L}$ & 8.00 & 91.10 & & \\
\hline & $1.0 \mathrm{mg} / \mathrm{L}$ & 0.00 & 100.00 & & \\
\hline & $2.0 \mathrm{mg} / \mathrm{L}$ & 0.00 & 100.00 & & \\
\hline \multirow{7}{*}{ Bellis $38 \%$ WG } & $0.1 \mathrm{mg} / \mathrm{L}$ & 76.00 & 15.60 & \multirow{7}{*}{$0.371 \mathrm{mg} / \mathrm{L}$} & \multirow{7}{*}{$>1.0 \mathrm{mg} / \mathrm{L}$} \\
\hline & $0.2 \mathrm{mg} / \mathrm{L}$ & 70.00 & 22.20 & & \\
\hline & $0.4 \mathrm{mg} / \mathrm{L}$ & 44.00 & 51.10 & & \\
\hline & $0.6 \mathrm{mg} / \mathrm{L}$ & 33.33 & 63.00 & & \\
\hline & $0.8 \mathrm{mg} / \mathrm{L}$ & 23.33 & 74.10 & & \\
\hline & $1.0 \mathrm{mg} / \mathrm{L}$ & 12.00 & 86.70 & & \\
\hline & $2.0 \mathrm{mg} / \mathrm{L}$ & 0.00 & 100.00 & & \\
\hline \multirow{7}{*}{ Collis $30 \% \mathrm{SC}$} & $1.0 \mu 1 / \mathrm{L}$ & 62.00 & 31.10 & \multirow{7}{*}{$3.402 \mu \mathrm{l} / \mathrm{L}$} & \multirow{7}{*}{$>12 \mu \mathrm{l} / \mathrm{L}$} \\
\hline & $2.0 \mu \mathrm{l} / \mathrm{L}$ & 54.33 & 39.70 & & \\
\hline & $4.0 \mu 1 / \mathrm{L}$ & 50.00 & 44.40 & & \\
\hline & $6.0 \mu 1 / \mathrm{L}$ & 45.33 & 49.70 & & \\
\hline & $8.0 \mu 1 / \mathrm{L}$ & 32.67 & 63.70 & & \\
\hline & $10.0 \mu \mathrm{l} / \mathrm{L}$ & 20.00 & 77.80 & & \\
\hline & $12.0 \mu \mathrm{l} / \mathrm{L}$ & 10.00 & 88.90 & & \\
\hline \multirow{7}{*}{ Uniform $39 \% \mathrm{SC}$} & $1.0 \mu 1 / \mathrm{L}$ & 76.00 & 15.60 & \multirow{7}{*}{$4.582 \mu 1 / L$} & \multirow{7}{*}{$>12 \mu \mathrm{l} / \mathrm{L}$} \\
\hline & $2.0 \mu \mathrm{l} / \mathrm{L}$ & 69.33 & 23.00 & & \\
\hline & $4.0 \mu \mathrm{l} / \mathrm{L}$ & 60.33 & 33.00 & & \\
\hline & $6.0 \mu \mathrm{l} / \mathrm{L}$ & 43.00 & 52.22 & & \\
\hline & $8.0 \mu 1 / \mathrm{L}$ & 38.67 & 57.00 & & \\
\hline & $10.0 \mu \mathrm{l} / \mathrm{L}$ & 22.67 & 74.80 & & \\
\hline & $12.0 \mu \mathrm{l} / \mathrm{L}$ & 13.67 & 84.80 & & \\
\hline Control & & 90.00 & 0.00 & & \\
\hline L.S.D at 0.05 & & 4.23 & & & \\
\hline
\end{tabular}

The tested fungicides i.e. Opus (at 1.0 and 2.0 $\mu \mathrm{l} / \mathrm{L}$ ), Switch (at 1.0 and $2.0 \mathrm{mg} / \mathrm{L}$ ) and Bellis (at 2.0 $\mathrm{mg} / \mathrm{L})$ recorded highest significant inhibition\% in radius growth $(100 \%)$ followed by both of Collis and Uniform at $12.0 \mu \mathrm{l} / \mathrm{L}$ (88.9\% and $84.8 \%$, respectively). Concerning the concentration giving $50 \%$ linear growth inhibition $\left(\mathrm{IC}_{50}\right)$, the tested fungicides i.e. Opus, Switch and Bellis were the most effective fungicides according to their $\mathrm{IC}_{50}$ values where recorded $0.127 \mathrm{mg} / \mathrm{L}, 0.230 \mathrm{mg} / \mathrm{L}$ and $0.371 \mathrm{mg} / \mathrm{L}$, respectively. Data in the same table show the minimum inhibition concentration which inhibits the linear growth of D. graminea over $90 \%$ for each tested fungicide. The calculated MIC $90 \%$ for Opus, Switch and Bellis recorded $0.8 \mathrm{ml} / \mathrm{L}, 0.8 \mathrm{mg} / \mathrm{L}$ and $>1.0$ $\mathrm{mg} / \mathrm{L}$, respectively. Meanwhile MIC $90 \%$ for the both of Collis and Uniform recorded $>12 \mu \mathrm{l} / \mathrm{L}$. In this respect, Kumar and Hooda (1995) tested 11 fungitoxicants in vitro against $D$. graminea (Pyrenophora graminea), G 696 (meta sulfavax) was the most inhibitory, followed by iprodione and tebuconazole.

\subsection{Effect of commercial plant oils:}

Three commercial plant oils were tested against $D$. graminea for their antifungal properties on radius growth. Data illustrated in Table (3) indicate that, all treatments significantly reduced the radius growth of $D$. graminea in comparing with control. Also, it well noticed that inhibition \% increased by increasing the plant oil concentration. The tested plant oils i.e. coriander, marjoram and caraway oils at concentration $15 \%$ recorded highest significant inhibition $\%$ in radius growth $(84.44 \%, 77.78 \%$ and $67.80 \%$, respectively). Concerning $\mathrm{IC}_{50}$ values, the coriander oil recorded the most effective plant oil $(7.40 \%)$ followed by marjoram oil $(9.05 \%)$ and caraway oil $(9.95 \%)$. The recorded 
calculated MIC for all tested plant oils were $>15 \%$. These results are convergent with those obtained by Daferera et al., 2000 and Sridhar et al., 2003, who reported that, the essential oils and their constituents have been found effective as antifungal agent. Also, Abou-Jawdah et al., (2002) reported that wild marjoram (Origanum syriacum) extract showed the highest and widest range of antimycotic activity against eight phytopathogenic fungi and it resulted complete inhibition of mycelial growth and nearly complete inhibition of spore germination of six fungi included in the assay, namely, Botrytis cinerea, Alternaria solani, Penicillium sp., Cladosporium sp., Fusarium oxysporum f. sp. melonis, and Verticillium dahlia. Singh et al., (2006) reported that coriander oil found to be highly active against four fungi from eight tested. Abou El-Soud et al., (2012) stated that complete inhibition of Aspergillus flavus growth was observed at $1000 \mathrm{ppm}$ concentration of coriander or caraway essential oils.

Table 3. Effect of some tested commercial plant oils on $D$. graminea fungus in vitro 7 days post incubation at $22 \pm 2^{\circ} \mathrm{c}$ in vitro:

\begin{tabular}{|c|c|c|c|c|c|}
\hline Treatment & $\begin{array}{c}\text { Concentration } \\
(\%)\end{array}$ & $\begin{array}{c}\text { Linear growth } \\
(\mathrm{mm})\end{array}$ & $\begin{array}{c}\text { Inhibition } \\
(\%)\end{array}$ & IC50 & $\mathrm{MIC}_{90}$ \\
\hline \multirow{8}{*}{ Coriander oil } & 4.0 & 70.00 & 22.22 & \multirow{9}{*}{$7.40 \%$} & \multirow{9}{*}{$>15 \%$} \\
\hline & 5.0 & 64.67 & 28.22 & & \\
\hline & 6.0 & 60.00 & 33.33 & & \\
\hline & 7.0 & 52.67 & 41.55 & & \\
\hline & 8.0 & 40.67 & 54.88 & & \\
\hline & 9.0 & 35.00 & 61.11 & & \\
\hline & 10.0 & 24.33 & 73.00 & & \\
\hline & 15.0 & 14.00 & 84.44 & & \\
\hline \multirow{8}{*}{ Marjoram oil } & 4.0 & 77.33 & 14.10 & & \\
\hline & 5.0 & 72.33 & 19.70 & \multirow{7}{*}{$9.05 \%$} & \multirow{6}{*}{$>15 \%$} \\
\hline & 6.0 & 65.67 & 27.00 & & \\
\hline & 7.0 & 60.00 & 33.33 & & \\
\hline & 8.0 & 53.67 & 40.33 & & \\
\hline & 9.0 & 50.00 & 44.44 & & \\
\hline & 10.0 & 33.67 & 62.56 & & \\
\hline & 15.0 & 20.00 & 77.78 & & \multirow{9}{*}{$>15 \%$} \\
\hline \multirow{8}{*}{ Carawy oil } & 4.0 & 82.00 & 8.80 & \multirow{8}{*}{$9.95 \%$} & \\
\hline & 5.0 & 75.33 & 16.33 & & \\
\hline & 6.0 & 70.00 & 22.22 & & \\
\hline & 7.0 & 65.00 & 27.80 & & \\
\hline & 8.0 & 57.67 & 35.50 & & \\
\hline & 9.0 & 45.00 & 50.00 & & \\
\hline & 10.0 & 40.00 & 55.60 & & \\
\hline & 15.0 & 28.67 & 67.80 & & \\
\hline Control & & 90.00 & 0.00 & & \\
\hline L.S.D at 0.05 & & 3.24 & & & \\
\hline
\end{tabular}

\subsection{Effect of bio-agents:}

The results in Table (4) reveal that, the both tested bio-agents reduced the mycelial growth of $D$. graminea in vitro. T. harzianum was most effective in mycelial inhibiting than B. subtilis. Data in Table (4) also showed that degree of inhibiting was maximazed with $T$. harzianum $(70.52 \%)$ after 4 days, but it was $55.55 \%$ with $B$. subtilis after 7 days. In the $4^{\text {th }}$ day of culture, the growth of $T$. harzianum contacted with the pathogen. At $7^{\text {th }}$ day $T$. harzianum was over grown the pathogen and severely inhibited the growth of the pathogen. In this respect, Tran (2010) reported that members of the Trichoderma genus are known as imperfect fungi, fast growing in culture and produce numerous green spores. Trichoderma species have become popular biological agents to protect crops against plant pathogens all over the world. Moreover, Mardanova et al., (2017) tested the potential antagonistic activity of some Bacillus subtilis strains ex. GM2 and GM5 against fungal pathogens in vitro and in vivo. Strains were characterized by their ability to inhibit growth of a number of phytopathogenic fungi. Also, Khalili et al., (2012) reported that Trichoderma isolates can significantly inhibit mycelium growth of pathogen in vitro. 
Table 4. Effect of some tested bio-agents on D. graminea fungus 2, 3,4 and 7 days post incubation at $22 \pm 2^{\circ} \mathrm{c}$ in vitro:

\begin{tabular}{lcccccccc}
\hline \multirow{2}{*}{ Treatment } & \multicolumn{3}{c}{ Linear growth $(\mathbf{m m})$} \\
\cline { 2 - 9 } & 2 DPI* & 3 DPI & 4 DPI & 7 DPI & 2 DPI & 3 DPI & 4 DPI & 7 DPI \\
\hline T. harzianum & 10.00 & 19.50 & 26.53 & 26.53 & 35.32 & 43.47 & 62.22 & 70.52 \\
B. subtilis & 10.71 & 22.74 & 39.50 & 40.00 & 30.72 & 34.00 & 43.75 & 55.55 \\
Control & $\mathbf{1 5 . 4 6}$ & $\mathbf{3 4 . 5}$ & $\mathbf{7 0 . 2 2}$ & $\mathbf{9 0 . 0 0}$ & $\mathbf{0 . 0 0}$ & $\mathbf{0 . 0 0}$ & $\mathbf{0 . 0 0}$ & $\mathbf{0 . 0 0}$ \\
\hline \multicolumn{1}{c}{ L.S.D at 0.05 } & $\mathbf{0 . 1 7 7}$ & $\mathbf{1 . 3 7}$ & $\mathbf{3 . 7 9}$ & $\mathbf{7 . 6 9}$ & & & \\
\hline * DPI= Days post inoculation. & & & & &
\end{tabular}

2. Control of barley leaf stripe disease under greenhouse conditions:

2.1. Using fungicides:

Data illustrated in Table (5) reveal that five fungicides i.e. Opus, Bellis, Switch, Collis and Uniform were screened against the barley leaf stripe disease caused by $D$. graminea under greenhouse conditions during the growing season 2016/2017. Three concentrations were tested for each fungicide i.e. recommended dose; half recommended dose and double recommended dose/kg barley grains cv. Giza 123. All tested fungicides had a great significant effect in decreasing the barley leaf stripe disease incidence in comparing with the control treatments. In this respect, Bellis treatment at $1 \mathrm{~g} / \mathrm{kg}$, Switch at 2 $\mathrm{g} / \mathrm{kg}$ and Opus at 2.0 and $4 \mathrm{ml} / \mathrm{kg}$ scored highest significant decrease in disease incidence percentage $(0.0 \%)$ and highest efficacy percentage (100\%). Jamshidi and Faramarzi, (2005) investigated the effects of using carboxin, thiram, imazalil, mancozeb, tilt [propiconazole] and maneb treatments on seed-borne inoculum of Pyrenophora graminea, the causal agent of barley stripe disease, in a greenhouse, imazalil was the best for disease control and was significantly better than the other treatments. Moreover Jamshidi et al., (2007) evaluated the effects of $0.5,1.0$ and $2.0 \%$ of carboxin $75 \mathrm{WP}$, carboxin-thiram 75WP, tilt [propiconazole] 250EC, carbendazim 60WP, Rovral [iprodione]-TS 52.5WP, benomyl 50WP, diniconazole 2WP, difenoconazole 3DS, maneb 80WP and mancozeb 80WP on barley infected grains with leaf stripe disease $(\sim 72 \%$ infection based on culture plate test method) under greenhouse conditions. The results showed that the most effective fungicides were Rovral-TS and mancozeb, while maneb and difeniconazole had the statistically least effect on the disease.

Table 5. Effect of some tested fungicides on barley leaf stripe disease under greenhouse conditions during 2016/2017 growing season:

\begin{tabular}{ccccc}
\hline \multicolumn{1}{c}{ Treatment } & Concentration & Disease incidence (\%) & Efficacy (\%) \\
\hline & $1 / 2 \mathrm{R}^{*}$ & $1.0 \mathrm{ml} / \mathrm{kg}$ & 0.50 & 98.76 \\
Opus 12.5\%SC & $\mathrm{R}$ & $2.0 \mathrm{ml} / \mathrm{kg}$ & 0.00 & 100.00 \\
& $2 \mathrm{R}$ & $4.0 \mathrm{ml} / \mathrm{kg}$ & 0.00 & 100.00 \\
\hline & $1 / 2 \mathrm{R}$ & $0.5 \mathrm{~g} / \mathrm{kg}$ & 1.50 & 96.20 \\
Switch 62.5\%WG & $\mathrm{R}$ & $1.0 \mathrm{~g} / \mathrm{kg}$ & 1.13 & 97.13 \\
& $2 \mathrm{R}$ & $2.0 \mathrm{~g} / \mathrm{kg}$ & 0.00 & 100.00 \\
\hline & $1 / 2 \mathrm{R}$ & $0.25 \mathrm{~g} / \mathrm{kg}$ & 3.30 & 91.40 \\
Bellis 38\% WG & $\mathrm{R}$ & $0.5 \mathrm{~g} / \mathrm{kg}$ & 2.50 & 93.67 \\
& $2 \mathrm{R}$ & $1.0 \mathrm{~g} / \mathrm{kg}$ & 0.00 & 100.00 \\
\hline & $1 / 2 \mathrm{R}$ & $0.25 \mathrm{ml} / \mathrm{kg}$ & 7.35 & 81.40 \\
Collis 30\%SC & $\mathrm{R}$ & $0.5 \mathrm{ml} / \mathrm{kg}$ & 5.25 & 86.70 \\
& $2 \mathrm{R}$ & $1.0 \mathrm{ml} / \mathrm{kg}$ & 4.00 & 89.90 \\
\hline & $1 / 2 \mathrm{R}$ & $0.5 \mathrm{ml} / \mathrm{kg}$ & 8.09 & 79.51 \\
Uniform 39\%SC & $\mathrm{R}$ & $1.0 \mathrm{ml} / \mathrm{kg}$ & 6.20 & 84.30 \\
& $2 \mathrm{R}$ & $2.0 \mathrm{ml} / \mathrm{kg}$ & 4.56 & $\mathbf{8 8 . 4 6}$ \\
\hline Control & & $\mathbf{3 9 . 5 0}$ & $\mathbf{0 . 0 0}$ \\
\hline L.S.D at $\mathbf{0 . 0 5}$ & & $\mathbf{1 . 0 2}$ & \\
\hline
\end{tabular}

* 1/2 HR= Half recommended dose; $\mathbf{R}=$ Recommended dose; $\mathbf{2} \mathbf{R}=$ Double recommended dose.

\subsection{Using commercial plant oils:}

Three commercial plant oils i.e. coriander, marjoram and caraway oils were screened against barley leaf stripe disease caused by $D$. graminea under greenhouse conditions, three concentrations were used for each one i.e. 9,10 and $15 \% / \mathrm{kg}$ barley grains cv. Giza 123. Data illustrated in Table (6) indicate that, all treatments significantly reduced the disease incidence percentage in comparing with both of control treatments. The most effective concentration in all tested plant oils was $15 \%$ which reduced the disease incidence $\%$ from $39.50 \%$ in 
control plant to $14.88 \%$ (coriander oil), $18.93 \%$ (marjoram oil) and 23.44 (caraway oil). In general, the most effective treatments were coriander followed by marjoram and caraway oils. In this regard, Daferera et al., (2000) and Sridhar et al., (2003) reported that, the essential oils and their constituents have been found effective as antifungal agent. Also Qasem and Aau-Blan (1996) showed that treating plants which biocides are nonphytotoxic, systemic and easily bio degradable. Goussous et al., (2010) reported that a number of plant species have been to possess natural substances that are toxic to several plant pathogenic fungi.

Table 6. Effect of some tested commercial plant oils on barley leaf stripe disease under greenhouse conditions during 2016/2017 growing season:

\begin{tabular}{cccc}
\hline Treatment & Concentration (\%) & Disease incidence (\%) & Efficacy (\%) \\
\hline & 9.0 & 20.67 & 47.67 \\
Coriander oil & 10.0 & 19.08 & 51.69 \\
& 15.0 & 14.88 & 62.33 \\
& 9.0 & 25.81 & 34.65 \\
Marjoram oil & 10.0 & 22.02 & 44.25 \\
& 15.0 & 18.93 & 52.07 \\
& 9.0 & 26.93 & 31.82 \\
Caraway oil & 10.0 & 25.58 & 35.24 \\
& 15.0 & 23.44 & 40.65 \\
\hline Control & $\mathbf{3 9 . 5 0}$ & $\mathbf{0 . 0 0}$ \\
\hline L.S.D at 0.05 & $\mathbf{0 . 7 3}$ & \\
\hline
\end{tabular}

\subsection{Using bio-agents:}

Compared with the disease control, Trichoderma harzianum and Bacillus subtilis had a positive effect reducing incidence of leaf stripe in Giza123 cultivar. Data in Table (7) indicate that higher concentration of the two bio-agents lead to the highest efficacy in controlling disease incidence. T. harzianum was in general the best in reducing incidence compared with $B$. subtilis. In this respect Kowsari et al., (2014) reported that, analysis of gene expression during these parasitizing events suggests that fungal cell walldegrading enzymes are actively produced by $T$. harzianum.

Table 7. Effect of some tested bio-agents on barley leaf stripe disease under greenhouse conditions during 2016/2017 growing season:

\begin{tabular}{|c|c|c|c|}
\hline Treatment & Concentration $(\%)$ & Disease incidence (\%) & Efficacy (\%) \\
\hline \multirow{3}{*}{ T. harzianum } & 1L:100L water* $\left(30 \times 10^{4} \mathrm{CFU} / \mathrm{mL}\right)$ & 24.51 & 37.94 \\
\hline & 1L:75L water $\left(40 \times 10^{4} \mathrm{CFU} / \mathrm{mL}\right)$ & 23.13 & 41.44 \\
\hline & 1L:50L water $\left(60 \times 10^{4} \mathrm{CFU} / \mathrm{mL}\right)$ & 17.90 & 54.68 \\
\hline \multirow{3}{*}{ B. subtilis } & 1L:100L water $\left(30 \times 10^{4} \mathrm{CFU} / \mathrm{mL}\right)$ & 28.16 & 28.7 \\
\hline & 1L:75L water $\left(40 \times 10^{4} \mathrm{CFU} / \mathrm{mL}\right)$ & 24.09 & 39.01 \\
\hline & 1L:50L water $\left(60 \times 10^{4} \mathrm{CFU} / \mathrm{mL}\right)$ & 20.24 & 48.75 \\
\hline Control & & 39.50 & 0.00 \\
\hline L.S.D at 0.05 & & 2.80 & \\
\hline
\end{tabular}

* 1L:100L water= 1 liter from original solution $\left(30 \times 10^{6} \mathrm{CFU} / \mathrm{mL}\right)$ diluted in 100 liter water to give $30 \times 10^{4} \mathrm{CFU} / \mathrm{mL}$ concentration; 1L:75 L= water= 1 liter from original solution $\left(30 \times 10^{6}\right)$ diluted in 75 liter water to give $40 \times 10^{4} \mathrm{CFU} / \mathrm{mL}$ concentration; 1L:50 L water= 1 liter from original solution $\left(30 \times 10^{6}\right)$ diluted in 50 liter water to give $60 \times 10^{4} \mathrm{CFU} / \mathrm{mL}$ concentration.

Surekha et al., (2014) reported that Trichoderma is a secondary opportunistic invader, fast growing fungus, strong spore producer, source of cell wall degrading enzymes and an important antibiotic producer. Paulitz and Belanger (2001) mentioned that during the past ten years, over 80 biocontrol products have been marketed worldwide. A large percentage of these have been developed for greenhouse crops. Products containing Trichoderma, Ampelomyces quisqualis, Bacillus, Ulocladium and Pseudomonas are being developed to control the primary foliar diseases,
Botrytis and powdery mildew in greenhouses could predominate over chemical pesticides.

\section{Control of barley leaf stripe disease and yield parameters under open field conditions:}

The present experiment was carried out using barley grains (Giza $123 \mathrm{cv}$.) naturally infected with barley leaf stripe disease at two locations i.e. the Experimental Station, ARC, Giza, and Kafr-Elhmam Station, ARC, El-Sharquia governorate, during the successive winter growing season 2016/2017 to evaluate the efficacy of different tested treatments 
against barley leaf stripe disease caused by $D$. graminea under open field condition.

\subsection{Using fungicides:}

Five different fungicides were tested against barley leaf stripe disease caused by $D$. graminea for their efficacy on disease incidence $\%$ and yield parameters at two locations i.e. Kafr-Elhmam and ElGiza Station during the growing season 2016/2017. Data in Table $(\mathbf{8 a} \& \mathbf{8 b})$ reveal that, all treatments significantly reduced the disease incidence $\%$ in comparing with control. In this respect, Opus fungicide treatment recorded the highest disease incidence reduction $(0.0 \%)$ at both locations followed by Switch, Bellis, Collis and Uniform, respectively. Regarding the effect of tested fungicides on barley yield parameters, results prove that, leaf stripe disease had an extreme effect on the yield parameter in untreated barley plants. On the other hand, all fungicide treatments significantly increased the assessed yield parameters in comparing with control treatment. Opus fungicide treatment recorded the most effective fungicide in increasing all yield parameters at the two stations, followed by Switch, Bellis, Collis and Uniform. In this respect, these results are agree with those found by Noworolnik (2012) who studied the effect of fungicides Alert 375 SC (flusilazole, carbendazym), Artea 330 EC (propiconazole, cyproconazole) and Capalo 337,5 SE (fenpropimorph, metrafenone, epoxyconazole) on grain yield, yield components, diseases occurrence on spring barley cultivars. All fungicides affected the increase in grain yield of spring barley cultivars, and reduced the intensity of fungal diseases caused by Pyrenophora graminea. Yield increase was related to the increase of grain mass per ear and 1000 grain weight. Also, Reis and Casa (2007) found that seed treatment effectiveness depends on chemical fungitoxicity, fungal sensitivity and seed coverage quality. Moreover Jayasena et al., (2002) evaluated ten fungicides as single application to control spot-type of net blotch of barley caused by $D$. teres f. sp. maculate at three locations during 1999-2000. They reported that under moderate disease severity, yield losses ranged from 17 $19 \%$ depending on location and under high disease severity, yield loss reached $32 \%$. They also found that pyraclestrobin, Propiconazole and mixture of Propiconazole with Iprodion were the most effective in controlling disease improving yield and grain quality.

Table 8a. Effect of some tested fungicides on barley leaf stripe disease under open field conditions at KafrElhmam station during 2016/2017 growing season:

\begin{tabular}{|c|c|c|c|c|c|}
\hline \multirow{3}{*}{ Treatment* } & \multicolumn{5}{|c|}{ Kafr-Elhmam Station } \\
\hline & \multirow[b]{2}{*}{ DI \% } & \multicolumn{4}{|c|}{$\begin{array}{c}\text { Yield parameters } \\
\end{array}$} \\
\hline & & $\begin{array}{l}\text { plant height } \\
\text { (cm) }\end{array}$ & $\begin{array}{c}\text { grain } \\
\text { number/spike (g) }\end{array}$ & $\begin{array}{c}\text { grain } \\
\text { weigh/spike (g) }\end{array}$ & $\begin{array}{c}\text { thousand kernel } \\
\text { weight (g) }\end{array}$ \\
\hline Opus $12.5 \% \mathrm{SC}$ at $2 \mathrm{ml} / \mathrm{kg}$ & 0.00 & 102.60 & 43.75 & 1.60 & 42.10 \\
\hline Switch $62.5 \%$ WG at $1 \mathrm{~g} / \mathrm{kg}$ & 1.07 & 100.00 & 40.93 & 1.50 & 40.18 \\
\hline Bellis $38 \% W G$ at $0.5 \mathrm{~g} / \mathrm{kg}$ & 2.40 & 97.35 & 38.61 & 1.35 & 37.83 \\
\hline Collis $30 \% \mathrm{SC}$ at $0.5 \mathrm{ml} / \mathrm{kg}$ & 4.70 & 93.43 & 37.13 & 1.22 & 35.33 \\
\hline Uniform $39 \% \mathrm{SC}$ at $1 \mathrm{ml} / \mathrm{kg}$ & 5.60 & 90.00 & 36.20 & 1.14 & 33.89 \\
\hline Control & 34.33 & 49.26 & 18.45 & 0.54 & 11.86 \\
\hline L.S.D at 0.05 & 1.46 & 2.00 & 1.62 & 0.1 & 1.80 \\
\hline
\end{tabular}

* The tested fungicides were applied at the recommended dose

Table $8 \mathbf{b}$. Effect of some tested fungicides on barley leaf stripe disease under open field conditions at El-Giza station during 2016/2017 growing season:

\begin{tabular}{|c|c|c|c|c|c|}
\hline \multirow[b]{3}{*}{ Treatment } & \multicolumn{5}{|c|}{ El-Giza Station } \\
\hline & \multirow[b]{2}{*}{ DI \% } & \multicolumn{4}{|c|}{ Yield parameters } \\
\hline & & $\begin{array}{c}\text { plant } \\
\text { height } \\
(\mathrm{cm})\end{array}$ & $\underset{\text { number/spike (g) }}{\text { grain }}$ & $\begin{array}{c}\text { grain } \\
\text { weigh/spike (g) }\end{array}$ & $\begin{array}{c}\text { thousand } \\
\text { kernel weight } \\
\text { (g) }\end{array}$ \\
\hline Opus $12.5 \%$ Sc at $2 \mathrm{ml} / \mathrm{kg}$ & 0.00 & 104.40 & 46.47 & 1.94 & 43.00 \\
\hline Switch $62.5 \%$ WG at $1 \mathrm{~g} / \mathrm{kg}$ & 0.60 & 101.74 & 44.87 & 1.73 & 41.87 \\
\hline Bellis $38 \%$ WG at $0.5 \mathrm{~g} / \mathrm{kg}$ & 1.90 & 98.87 & 43.19 & 1.58 & 39.62 \\
\hline Collis $30 \% \mathrm{SC}$ at $0.5 \mathrm{ml} / \mathrm{kg}$ & 4.00 & 94.74 & 40.00 & 1.42 & 37.60 \\
\hline Uniform $39 \% \mathrm{SC}$ at $1 \mathrm{ml} / \mathrm{kg}$ & 4.85 & 92.53 & 38.22 & 1.32 & 34.87 \\
\hline Control & 30.00 & 50.00 & 19.33 & 0.61 & 12.07 \\
\hline L.S.D at 0.05 & 1.78 & 1.22 & 1.50 & 0.140 & 1.50 \\
\hline
\end{tabular}

\subsection{Using commercial plant oils:}

Data illustrated in Table $(9 \mathbf{9} \boldsymbol{\&} \mathbf{9 b})$ reveal that, three commercial plant oils were screened against the barley leaf stripe disease caused by $D$. graminea under open field conditions during the growing season 2016/2017 at two locations ex. Kafr-Elhmam and ElGiza Stations. The results reveal that, all tested treatments significantly reduced leaf stripe disease 
incidence \% compared with control treatment. The lowest disease incidence in both stations i.e. KafrElhmam and El-Giza was recorded on plant treated with coriander oil $(13.25 \%, 10.33 \%$, respectively) followed by marjoram oil $(19.00 \%, 15.60 \%$, respectively) and caraway oil $(22.33 \%, 19.12 \%$, respectively). Considering the effect of the tested plant oils on yield parameters, decreasing in disease incidence correlated negatively with assessed yield parameters. In this respect, coriander oil treatment at the two locations (Kafr-Elhmam and El-Giza) recorded the highest yield parameters i.e. plant height $(79.73,81.04 \mathrm{~cm})$, grains number/spike $(32.0,34.0)$, grains weight/spike $(0.97$, $1.05 \mathrm{~g})$ and $1000 \mathrm{kernel}$ weight $(29.00,31.00 \mathrm{~g})$ compared with untreated control (49.26, 50.00 $\mathrm{cm}),(18.45,19.33)(0.54,0.61 \mathrm{~g})$ and $(11.86,12.07 \mathrm{~g})$, respectively.

Table 9a. Effect of some tested commercial plant oils on barley leaf stripe disease under open field conditions at Kafr-Elhmam station during 2016/2017 growing season:

\begin{tabular}{cccccc}
\hline & \multicolumn{5}{c}{ Kafr-Elhmam Station } \\
\cline { 2 - 6 } Treatment & DI \% & $\begin{array}{c}\text { Ylant } \\
\text { height }(\mathbf{c m})\end{array}$ & $\begin{array}{c}\text { Yield parameters } \\
\text { number/spike }(\mathbf{g})\end{array}$ & $\begin{array}{c}\text { grain } \\
\text { weigh/spike (g) }\end{array}$ & $\begin{array}{c}\text { thousand } \\
\text { kernel weight } \\
(\mathbf{g})\end{array}$ \\
\hline Coriander oil at 15\% & 13.25 & 79.73 & 32.00 & 0.97 & 29.00 \\
Marjoram oil at 15\% & 19.00 & 75.63 & 29.00 & 0.82 & 27.00 \\
Caraway oil at 15\% & 22.33 & 72.00 & 28.00 & 0.73 & 26.60 \\
\hline Control & $\mathbf{3 4 . 3 3}$ & $\mathbf{4 9 . 2 6}$ & $\mathbf{1 8 . 4 5}$ & $\mathbf{0 . 5 4}$ & $\mathbf{1 1 . 8 6}$ \\
\hline L.S.D at 0.05 & $\mathbf{3 . 8 9}$ & $\mathbf{2 . 1 6}$ & $\mathbf{1 . 6 4}$ & $\mathbf{0 . 0 7}$ & $\mathbf{1 . 3 6}$ \\
\hline
\end{tabular}

Table 9b: Effect of some tested commercial plant oils on barley leaf stripe disease under open field conditions at El-Giza station during 2016/2017 growing season:

\begin{tabular}{cccccc}
\hline & \multicolumn{5}{c}{ El-Giza Station } \\
\cline { 2 - 6 } Treatment & \multirow{2}{*}{ DI \% } & $\begin{array}{c}\text { plant } \\
\text { height }(\mathbf{c m})\end{array}$ & $\begin{array}{c}\text { Yrain } \\
\text { number/spike }(\mathbf{g})\end{array}$ & $\begin{array}{c}\text { grain } \\
\text { weigh/spike (g) }\end{array}$ & $\begin{array}{c}\text { thousand kernel } \\
\text { weight (g) }\end{array}$ \\
\hline Coriander oil at 15\% & 10.33 & 81.04 & 34.00 & 1.05 & 31.00 \\
Marjoram oil at 15\% & 15.60 & 77.17 & 32.00 & 0.96 & 29.07 \\
Caraway oil at 15\% & 19.12 & 73.50 & 30.00 & 0.89 & 27.13 \\
\hline Control & $\mathbf{3 0 . 0 0}$ & $\mathbf{5 0 . 0 0}$ & $\mathbf{1 9 . 3 3}$ & $\mathbf{0 . 6 1}$ & $\mathbf{1 2 . 0 7}$ \\
\hline L.S.D at 0.05 & $\mathbf{4 . 0 3}$ & $\mathbf{1 . 3 0}$ & $\mathbf{2 . 2 0}$ & $\mathbf{0 . 1 0}$ & $\mathbf{0 . 9 0}$ \\
\hline
\end{tabular}

In this respect Bowers and Locke (2004) reported that various natural plant extracts can reduce populations of plant pathogens and control disease development and have potential as environmentally safe alternatives and as components in integrated pest management programs. Also, Preethy and Nalini (2015) suggested that essential oil can be used in quality control of fungi. Essential oils possessed volatile oils, flavonoids and phenols. Daouk et al., (1994) evaluated the antifungal activity of origanum oil extracted from (Origanum syriacum L.) plants against Aspergillus niger, Fusarium oxysporum, and Penicillium species. The oil exhibited strong inhibitory action against the three fungi tested.

\subsection{Using bio-agents:}

Data in Table (10a \& 10b) showed that, the barley plants treated with the two tested bio-agents (Trichoderma harzianum and Bacillus subtilis) resulted suppression in disease incidence as well as increment in yield parameters. They successfully manage the disease in the field. Using $T$. harzianum and B. subtilis recorded disease incidence $16.25 \%$,
$13.33 \%$ and $19.86 \%, 16.35 \%$ at Kafr-Elhmmam and El-Giza, respectively. As for yield parameters, results indicated that the two tested bio-agents increased yield components compared with control plants. The highest effect in both stations was recorded with $T$. harzianum application on plant height (70.87, $72.20 \mathrm{~cm})$, grains number/ spike $(27.27,29.00)$, grains weight /spike $(0.70, .85 \mathrm{~g})$ and weight of 1000 grains $(25.00,25.77 \mathrm{~g})$ at Kafr-Elhmam and El-Giza respectively. In this regard, Hasan et al., (2012) assessed the antagonistic effect of Trichoderma harzianum on some seed-borne fungal pathogens of wheat. They found that emergence of plants was increased by $15.93 \%$ over that obtained with the control treatment, and seedling infection was reduced significantly and leaf blight severity was decreased from 22 to 11 at the heading stage. They also recorded at harvest, the number of tillers per plant was increased by $50 \%$, the yield was increased by $31.58 \%$, and the 1000 -seed weight was increased by 21\%. Also, Koch et al., (2006) evaluated the activity of four Trichoderma strains against $D$. graminea and $D$. teres on barley in the field. In four experiments 
under controlled conditions, Tillecur (mustard powder) showed consistent activity (mean: $78 \%$ efficacy) against barley leaf stripe. Perello et al., (2008) determine the effect of six isolates of Trichoderma harzianum the incidence and severity of tan spot, caused by Pyrenophora tritici-repentis (anamorph: Drechslera tritici-repentis) under field conditions. In 2003, two of the isolates assayed (T5, T7) showed the best performance against the disease applied as seed treatments. Disease severity reduced by 16 to $35 \%$ in comparison with the control.

Table 10a. Effect of some bio-agents on barley leaf stripe disease and yield parameters under open field conditions at Kafr-Elhmam Station during 2016/2017 growing season:

\begin{tabular}{|c|c|c|c|c|c|}
\hline \multirow[b]{3}{*}{ Treatment } & \multicolumn{5}{|c|}{ Kafr-Elhmam Station } \\
\hline & \multirow[b]{2}{*}{ DI \% } & \multicolumn{4}{|c|}{ Yield parameters } \\
\hline & & $\begin{array}{c}\text { plant } \\
\text { height }(\mathrm{cm})\end{array}$ & $\begin{array}{c}\text { grain } \\
\text { number/spike (g) }\end{array}$ & $\begin{array}{c}\text { grain } \\
\text { weigh/spike (g) }\end{array}$ & $\begin{array}{l}\text { thousand } \\
\text { kernel weight } \\
\text { (g) }\end{array}$ \\
\hline T. harzianum (1:50)* & 16.25 & 70.87 & 27.27 & 0.70 & 25.00 \\
\hline B. subtilis $(1: 50)$ & 19.86 & 68.83 & 25.75 & 0.68 & 22.83 \\
\hline Control & 34.33 & 49.26 & 18.45 & 0.54 & 11.86 \\
\hline L.S.D at 0.05 & 2.27 & 1.5 & 1.16 & 0.04 & 1.96 \\
\hline
\end{tabular}

* 1L:50 L water $=1$ liter from original solution $\left(30 \times 10^{6}\right)$ diluted in 50 liter water to give $60 \times 10^{4} \mathrm{CFU} / \mathrm{mL}$ concentration.

Table 10b. Effect of some bio-agents on barley leaf stripe disease and yield parameters under open field conditions at El-Giza Station during 2016/2017 growing season:

\begin{tabular}{lccccc}
\hline & \multicolumn{5}{c}{ El-Giza Station } \\
\cline { 2 - 6 } Treatment & & \multicolumn{4}{c}{ Yield parameters } \\
\cline { 2 - 6 } & DI \% & $\begin{array}{c}\text { plant } \\
\text { height }(\mathbf{c m})\end{array}$ & $\begin{array}{c}\text { grain } \\
\text { number/spike }(\mathbf{g})\end{array}$ & $\begin{array}{c}\text { grain } \\
\text { weigh/spike (g) }\end{array}$ & $\begin{array}{c}\text { thousand } \\
\text { kernel weight } \\
(\mathbf{g})\end{array}$ \\
\hline T. harzianum (1:50) & 13.33 & 72.20 & 29.00 & 0.85 & 25.77 \\
B. subtilis $(\mathbf{1 : 5 0 )}$ & 16.35 & 70.03 & 28.00 & 0.82 & 23.37 \\
\hline Control & $\mathbf{3 0 . 0 0}$ & $\mathbf{5 0 . 0 0}$ & $\mathbf{1 9 . 3 3}$ & $\mathbf{0 . 6 1}$ & $\mathbf{1 2 . 1 0}$ \\
\hline L.S.D at $\mathbf{0 . 0 5}$ & $\mathbf{4 . 7 7}$ & $\mathbf{2 . 4 1}$ & $\mathbf{2 . 0 8}$ & $\mathbf{0 . 0 9}$ & $\mathbf{0 . 9 7}$ \\
\hline
\end{tabular}

4- Determination of total phenol content and activities of some plant defense-related enzymes in treated barley plants with fungicides, commercial plant oils and bio-agents to control $D$. graminea under greenhouse conditions:

Data in Table (11) indicate that, all tested treatments i.e. fungicides, commercial plant oils and bio-agents affected positively total phenol content and activities of some plant defense-related enzymes in leaves of treated barley plants compared with the infected and non-infected control treatment. In this respect, in general, the highest increases induced by the tested fungicides followed by commercial plant oils and bio-agents.

Considering total phenol content, the highest increase was recorded by the tested fungicides $e x$. Opus, Switch, Bellis, Collis and Uniform, respectively. Considering plant oils, coriander oil treatment followed by marjoram and caraway oil treatments scored highest increase in total phenol content. Meanwhile, barley plants treated with bioagents i.e. T. harzianum and B. subtilis recorded lowest increase in total phenol content in comparing with control treatment. Phenolics are one of the largest and most diverse groups of plant active substances. Phenolic compounds are plant secondary metabolites playing important roles in plant resistance. Kulbat (2016) reported that these compounds take part in the regulation of seed germination and cooperate in regulating the growth of plants, also taking part in defense responses during infection, excessive sun exposure, injuries and heavy metal stress. One of the most important features of phenolic compounds is antioxidant activity which is closely related to their chemical structure. Also Onaran and Bayram (2018) suggested that phenolic compounds in natural antifungal agents may offer positive results in the control of plant pathogens. Nagaveni (2005) recorded significant positive correlation between phenolic content and leaf blight disease resistance in barley where, higher levels of phenols were observed in diseased barley plants.

Also, data in Table (11) reveal that, all tested treatments positively increased the activities of some determined plant defense-related enzymes i.e. polyphenole oxidase, peroxidase and chitinase enzymes in leaves of barley plants compared with control $(D$. graminea). In this respect, the highest increase was recorded by Opus, Switch, Bellis, Collis and Uniform, respectively. Also, coriander oil treatment followed by marjoram and caraway oils treatments scored highest increase in activities of polyphenole oxidase, peroxidase and chitinase enzymes while, barley plants treated with 
bio-agents i.e. T. harzianum and B. subtilis recorded lowest increase in comparing with control treatment.

In this regard Dheeba et al., (2015) reported that the increase in some biochemical parameters, pigment system and antioxidant enzymes were corresponded with the reduction of disease severity. Yedidia $\boldsymbol{e t}$ al., (2003) mentioned that polyphenol oxidase catalyzing the oxygen dependent oxidation of phenols to quinones is assumed to be involved in plant defense against pests and pathogens. Peroxidase plays an important role in biosynthesis of plant cell wall components viz., lignin, suberin, lignifications and wall thickening as part of defense response to pathogens particularly fungi (Gaspar et al., 1982 and Lamport, 1986).

Table 11. Effect of some tested treatments on total phenol content and activities of some plant defense-related enzymes in treated barley plants with fungicides, commercial plant oils and bio-agents to control $D$. graminea under greenhouse conditions:

\begin{tabular}{|c|c|c|c|c|c|c|c|c|}
\hline \multirow[b]{3}{*}{ Treatment* } & \multirow{2}{*}{\multicolumn{2}{|c|}{ Total phenols }} & \multicolumn{4}{|c|}{ Oxidative enzymes } & \multicolumn{2}{|c|}{ Chitinase } \\
\hline & & & \multicolumn{2}{|c|}{ Polyphenol oxidase } & \multicolumn{2}{|c|}{ Peroxidase } & \multirow[b]{2}{*}{$\begin{array}{c}\text { mMaga/g } \\
\text { FW/60 } \\
\text { min* }\end{array}$} & \multirow[b]{2}{*}{ Efficacy \% } \\
\hline & $\begin{array}{c}\text { mg } \\
\text { cat/g } \\
\text { DW }\end{array}$ & $\begin{array}{c}\text { Efficacy } \\
\%\end{array}$ & $\begin{array}{c}\Delta 420 / 30 \\
\mathrm{~min} / \mathrm{g} \\
\mathrm{FW}\end{array}$ & Efficacy \% & $\begin{array}{c}\Delta 425 / 15 \\
\mathrm{~min} / \mathrm{g} \\
\mathrm{FW}\end{array}$ & Efficacy \% & & \\
\hline Opus $12.5 \% \mathrm{SC}$ & 42.6 & 1207.7 & 14.41 & 332.7 & 64.25 & 350.9 & 28.27 & 444.7 \\
\hline $\begin{array}{l}\text { Switch } \\
62.5 \% \mathrm{WG}\end{array}$ & 37.1 & 1039.3 & 12.55 & 276.9 & 60.15 & 322.1 & 25.38 & 389.0 \\
\hline Bellis $38 \% \mathrm{WG}$ & 30.6 & 838.7 & 11.25 & 237.8 & 54.26 & 280.8 & 22.13 & 326.4 \\
\hline Collis $30 \%$ SC & 26.6 & 716.0 & 10.56 & 217.1 & 46.91 & 229.2 & 18.70 & 260.3 \\
\hline $\begin{array}{l}\text { Uniform } \\
39 \% \mathrm{SC}\end{array}$ & 22.1 & 576.4 & 9.72 & 191.9 & 40.22 & 182.2 & 15.70 & 202.5 \\
\hline Mean & 31.8 & 875.6 & 11.7 & 251.3 & 53.2 & 273.0 & 22.0 & 324.6 \\
\hline Coriander oil & 17.8 & 447.2 & 8.25 & 147.7 & 35.33 & 147.9 & 13.44 & 159.0 \\
\hline Marjoram oil & 14.5 & 344.8 & 7.11 & 113.5 & 33.24 & 133.3 & 12.22 & 135.5 \\
\hline Caraway oil & 12.4 & 278.8 & 6.22 & 86.8 & 30.12 & 111.4 & 10.25 & 97.5 \\
\hline Mean & 14.9 & 357.0 & 7.2 & 116.0 & 32.9 & 130.9 & 12.0 & 130.6 \\
\hline T. harzianum & 10.8 & 230.7 & 5.25 & 57.7 & 26.27 & 84.4 & 9.42 & 81.5 \\
\hline B. subtilis & 9.6 & 194.5 & 5.05 & 51.7 & 24.14 & 69.4 & 7.50 & 44.5 \\
\hline Mean & 10.2 & 212.6 & 5.2 & 54.7 & 25.2 & 76.9 & 8.5 & 63.0 \\
\hline Control & 3.3 & 0.0 & 3.3 & 0.0 & 14.3 & 0.0 & 5.2 & 0.0 \\
\hline
\end{tabular}

\section{References}

Abou El-Soud, N.H.; Deabes, M.M.; Abou ElKassem, L.T. and Khalil, M.Y. (2012). Antifungal activity of family apiaceae essential oils. J. App. Sci. Res., 8(10): 4964-4973.

Abou-Jawdah, Y.; Sobh, Y. and Salameh, A. (2002). Antimycotic activities of selected plant flora, growing wild in Lebanon, against phytopathogenic fungi. J. Agric. Food Chem., 50 (11): 3208-3213.

Allam, A.I. and Hollis, J.P. (1972). Sulfide inhibition of oxidase in rice roots. Phytopathology, 62: 634-639.

Anand, T.; Raguchander, T.; Karthikeyan, G.; Prakasam, V. and Samiyappan, R. (2007). Chemically and biologically mediated systemic resistance in cucumber (Cucumis sativus L.) against Pseudoperonospora cubensis and Erysiphe cichoracearum. Phytopathol. Med., 46: 259-271.

Bary, H.G. and Thorpe, W.V. (1954). Analysis of phenolic compounds of interest in metabolism. Methods of chemical analysis, 1: 27-51.
Boller, T. and Mauch, F. (1988). Chitinase from Phaseolus vulguris, leaves. Meth. Enzymol, 161: $479-484$

Bowers, J.H. and Locke, J.C. (2004). Effect of formulated plant extracts and oils on population density of Phytophthora nicotianae in soil and control of Phytophthora blight in the greenhouse. Plant Dis., 88: 11-16.

Brown, W. (1924). Two mycelial methods. II. A method of isolation single strains on fungi by cutting out a hyphal tip. Ann. Bot., 38: 402-404.

Daferera, D.J.; Ziogas, B.N. and Polissiou, M.G. (2000). The effectiveness of plant essential oils on the growth of Botrytis cinerea, Fusarium sp. and Clavibacter michiganensis sub sp. Michiganensis. Crop Protec., 22(1): 39-44.

Daouk, R.; Dagher, S.M. and Sattout, E. (1994). Antifungal activity of the Essential oil of Origanum syriacum L. J. Food Protect. 58(10): 1147-1149.

Dheeba, B.; Niranjana, R.; Sampathkumar, P.; Kannan, K. and Kannan, M. (2015). Efficacy of neem (Azadirachta indica) and tulsi (Ocimum sanctum) leaf extracts against early blight of 
tomato. Proc. Nat. Acad. Sci., India, Sect. Biol. Sci., 85(1):327-336.

Gaspar, T.; Penel, C.; Thorpe, T. and Greppin, H. (1982). Peroxidases 1970-1980. A survey of their biochemical and physiological roles in higher plants. Switzerland: Univ. de Geneva, Centre de Botanique, $324 \mathrm{p}$.

Goussous, S.J.; Abu El-Samen, F.M. and Tahhan, R.A. (2010). Antifungal activity of several medicinal plants extracts against the early blight pathogen (Alternaria solani). Arch. Phytopathol. Plant Protect., 43: 1745-1757.

Hasan, M.M.; Rahman, S.M.; Kim, G.H.; Elgorban, A.M. and Oh. D.H. (2012). Antagonistic potentiality of Trichoderma harzianum towards seed-borne fungal pathogens of winter wheat cv. Protiva in vitro and in vivo. $\mathrm{J}$. Microbiol. Biotechnol. 22(5): 585-91.

Hornby, D. (1990). Biological control of soil-borne plant pathogens. CAB International, Wallingford UK.

Ito, D. (1930). On some new ascigerous stages of the species of Helminthosporium parasitic on cereals. Supplement of Proceedings of the Imperial Academy of Japan 6: 352-355.

Jamshidi, S.; Abdi, M.; Faramarzi, A. (2005). The effect of thermal and chemical treatment on seedborn inoculum of Pyrenophora graminea, the causal agent of barley stripe disease in greenhouse. Journal of New Agric. Sci., 1(1): 2025.

Jamshidi, S.; Ghaffari, A.; Sadeghzadeh, M. and Mianaji, M. (2007) Assessment of barley seeds chemical treatments with some conventional fungicides on barley stripe control. J. New Agric. Sci. 3(6): 7-25.

Jayasena, K.W.; Loughman, R. and Majewski, J. (2002). Evaluation of fungicides in control of spot-type net blotch on barley. Crop Prot. 21: 6369.

Kavak, H. (2004). Pyrenophora graminea in fields sown-spring barley Angora in arid district of Turkey. Pakistan. J. Biological Sciences. 7(7): 1225-1228.

Khalili, E.; Sadravi, M.; Naeimi, S. and Khosravi, V. (2012). Biological control of rice brown spot with native isolates of three Trichoderma species. Brazilian J. Microbiol., 297-305.

Koch, E.; Weil, B.; Wchter, R.S. and Wohlleben, H. (2006). Evaluation of selected microbial strains and commercial alternative products as seed treatments for the control of Tilletia tritici, Fusarium culmorum, Drechslera graminea and D. teres .J. Plant Dis. and Protec., 113 (4):150-158.

Kowsari, M.; Zamani, M.R. and Motallebi, M. (2014). Enhancement of Trichoderma harzianum activity against Sclerotinia sclerotiorum by over expression of chitosan. Iranian J. Biotechnology, 12: 26-31.
Kulbat, K. (2016). The role of phenolic compounds in plant resistance. Biotechnol. Food Sci, 80 (2): 97-108.

Kumar, S.V. and Hooda, I. (1995). Seed treatment for stripe disease of barley caused by Drecshlera graminea. Plant Dis. Res., 10: 126-129.

Lamport, D.T.A. (1986). Role of peroxidases in cell wall genesis. Molecular and physiological aspects of plant peroxidases. (Eds.): Greppin H.; Penel C. and Gasper, T. Univ. Geneva Center de Botanique, 199-208 pp.

Lockwood, J.L. (1988). Evolution of concepts associated with soil-borne plant pathogen. Annu. Rev. phytopathol., 26: 93-121.

Mahmoud, (Noher), A.; Khalifa, M.M.A. and AbouZeid, N.M. (2013). Performance of some bio fungicides on the most onion economic diseases compared to recommended fungicide in Egypt, II Downy mildew and purple blotch diseases control and their economical feasibility. Egyptian Journal of Applied Science, 28 (1): 66-92.

Mardanova, A.M.; Hadieva, G.F.; Lutfullin, M.T.; Khilyas, I.V.; Minnullina, L.F.; Gilyazeva, A.G.; Bogomolnaya, L.M. and Sharipova, M.R. (2017). Bacillus subtilis strains with antifungal activity against the phytopathogenic fungi. Agric. Sci., 8: 1-20.

Matta, A. and Dimond, A.E. (1963). Symptoms of Fusarium wilt in relation to quantity of fungus and enzyme activity in tomato stems. Phytopathology, 53: 574-587.

Moussa, A.L.; Morsy, E.M.; Shaltout, A.M.A. and Fahmy, S.S. (2007). Efficiency of some bacterial strains for controlling limb rot diseases of peanut in sandy soil. In $12^{\text {th }}$ conference of microbiology, Cairo, Egypt, March (pp. 18-20).

Nagaveni, T. (2005). Resistance factors for leaf blight of barley caused by Helminthosporium sativum Pam., King and Bakke. M.Sc. (Agri.) Thesis, Univ. Agric. Sci, Dharwad.

Naik, M.K.; Prasad, Y.; Bhat, K.V. and Rani, G.S. (2010). Morphological, physiological, pathogenic and molecular variability among isolates of Alternaria solani from tomato. Indian phytopthol., 63: 168-173.

Nene, Y.L and Thapliyal, R.N. (1993). Evaluation of fungicides in fungicides for plant disease control (3rd ed.). Oxford, IHB Pub. Co. New Delhi.P. 331 .

Noaman, M.M. (2008). Barley development in Egypt. Proceedings of the $10^{\text {th }}$ International Barley Genetics Symposium. Alexandria, Egypt, 3-15.

Noworolnik, K. (2012). Effect of fungicides on yielding and grain quality of malting barley cultivars. Plant Prot., 52(3): 642-645.

Nwachukwu, E.O. and Umechurub, C.I. (2001). Antifungal activities of some leaf extracts on seedborne fungi of African yam bean seeds, seed 
germination and seedling emergence. J. Appl. Sci. Environ. Mgt., 5 (1): 29-32.

Onaran, A. and Bayram, M. (2018). Determination of antifungal activity and phenolic compounds of endemic Muscari aucheri (Boiss.) baker extract. J. Agric. Fac. Gaziosmanpasa Univ., 35 (1): 60-67.

Paulitz, T.C. and Belanger, R.R. (2001). Biological control in greenhouse systems. Ann. Rev. Phytopathol., 39:103-133.

Pecchioni, N.; Vale, G.; Toubia-Rahme, H.; Faccioli, P.; Terzi, V. and Delogu, G. (1999). Barley-Pyrenophora graminea interaction: QTL analysis and gene mapping. Plant Breed., 118: 29-35.

Perello, A.; Moreno, V.; Mo'naco, C. and Simo, M.R. (2008). Effect of Trichoderma spp. isolates for biological control of tan spot of wheat caused by Pyrenophora tritici-repentis under field conditions. Argentina Bio. Control, 53: 895-904.

Preethy, M.; Nalini, M. (2015). Quality control profiling, antifungal and in vivo cytotoxic potential of Origanum marjoram L. Int. J. Pharma and Bio. Sci., 6(2): 634 - 640

Qasem, J.R. and Aau-Blan, H.A. (1996). Fungicidal activity of some common weed extracts against different plant pathogenic fungi. J. Phytopathol., 144 (3):157-161.

Reis, E.M. and Casa, R.C. (2007). Doencas dos cereals de inverno: diagnose, epidemiologia e control Lages: Graphel, 176p.

Robert, T.R; Huston, D.H.; Lee, P.W.; Nicholls, P.H and plimmer, I.R. (1996). Metabolic pathway of agro chemicals: part 2: insecticides and fungicides. Cambridge, NK, the Royal society of chemistry, $1090 \mathrm{p}$.

Simons, T.O. and Ross, A.F. (1971). Changes in phenol metabolism associated with induced systemic resistance to Tobacco mosaic virus in Sumsun NN Tobacc. Phytopathology, 61(10): 1261-1265.

Singh, G.; Maurya, S.; Lampasona, M.P. and Catalan, C.A.N. (2006). Studies on essential oils, Part 41.Chemical composition, antifungal, antioxidant and sprout suppressant activities of coriander (Coriandrum sativum) essential oil and its Oleoresin. Flavour Fragr. J., 21: 472-479.
Skidmore, A.M. and Dickenson, C.H. (1976). Colony interaction and hyphal interference between Septoria nodorum and phylloplane fungi. Trans. Brit-Mycol. Soc., 66(11): 57-64.

Snedecor, G.W. and Cochran, W.G. (1989). Statistical methods. Oxford and J. PH. Publishing Com. $8^{\text {th }}$ edition.

Sridhar, S.R.; Rajagopal, R.V.; Rajavel, R.; Masilamani, S. and Narasimhan, S. (2003). Antifungal activity of some essential oils. J. Agric. Food Chem., 51: 7596-7599.

Surekha, C.; Neelapu, N.; Prasad, B.S. and Ganesh, S. (2014). Induction of defense enzymes and phenolic content by Trichoderma viride in Vigna mungo infested with Fusarium oxysporum and Alternaria alternata. Int. J. Agric. Sci. and Res., 4: 31-40.

Tran, N.H. (2010). Using Trichoderma species for biological control of plant pathogens in Vietnam. J. ISSAAS, 16 (1): 17-21.

Velazhahan, R. and Vidhyasekaran, P. (1994). Role of phenolic compounds, peroxidase and polyphenol oxidase in resistance of ground nut to rust. Acta phytopathologica et Entomdegica Hungarica, 29: 23-29.

Wang, H.; Hwang, S.F.; Chang, K.F.; Turnbull, G.D. and Howard, R.J. (2003). Suppression of important pea diseases by bacterial antagonists. Biocontrol, 48(4): 447-460.

Yedidia, I.; Shoresh, M.; Kerem, Z.; Benhamou, N.; Kapulnik, Y. and Chet, I. (2003). Concomitant induction of systemic resistance to Pseudomonas syringae pv. lachrymans in cucumber by Trichoderma asperellum (T-203) and the accumulation of phytoalexins. App. and Env. Microb., 69:7343-53.

Zadocks, J.C.; Chang, T.T. and Konzak, C.F. (1974). A decimal code for the growth stages of cereals. Wheat Research. 14: 415-421.

Zare, L. and Hashemi, S. (2013). Leaf stripe of barley caused by pyrenophora graminea, occurrence in barley seeds in Iran. Int J. Farm \& Alli Sci., 2(6): 129-132.Wang, H.; Hwang, S.F.; Chang, K.F.; Turnbull,G.D. and Howard, R.J. (2003). Suppression of important pea diseases by bacterial antagonists. Biocontrol, 48(4): 447-460. 
كفاءة بعض المبيدات الفطرية والزيوت النباتية وعوامل المقاومة الحيوية ضد Drechslera graminea المسبب لمرض التخطيط فى الثعير

أميرة مفرح عبد العظيم"، نوال عبد المنعم عيسى"، جهاد محمد الهباء"، فاتن كامل النشار"، ابراهيم عبد المنعم ابراهيم الفقى" ".

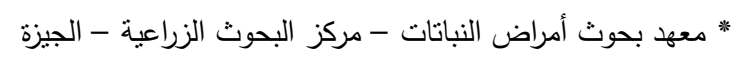

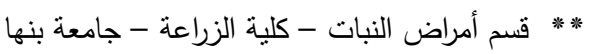

نم دراسة ثأثير استخدام خمسة مبيدات فطرية وثلاثة زيوت نباتية واثثين من عوامل المقاومة الحيوية تحت ظروف المعطل والصوبة والحقل فى مقاومة

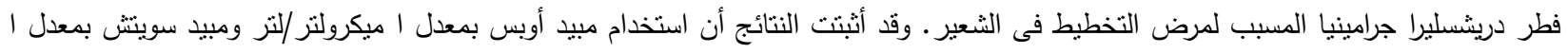

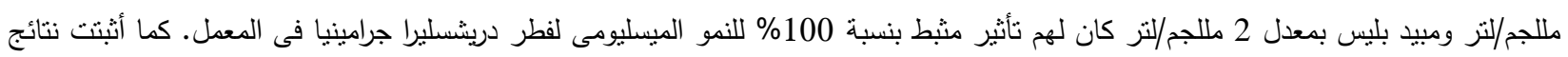
استخدام الزيوت النباتية لمقاومة الفطر فى المعل أن زيت الكزبرة اعطى اعلى معدل لتثبيط النمو الميسليومى وذلك باستخدامه عند تركيز 15\%

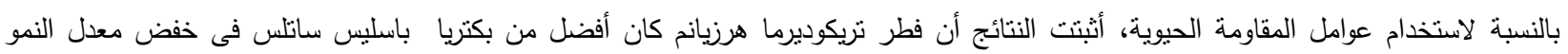

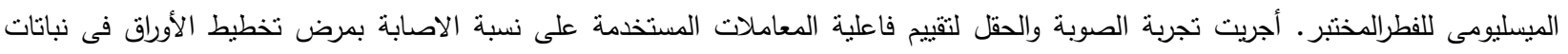

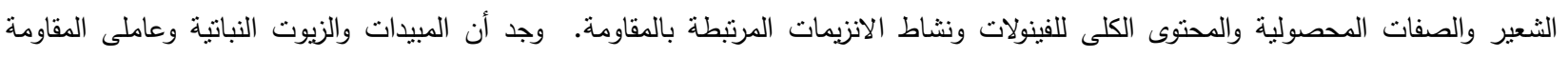

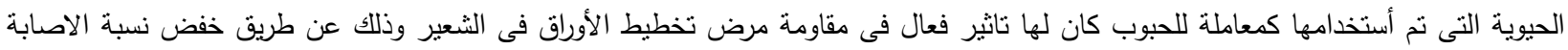

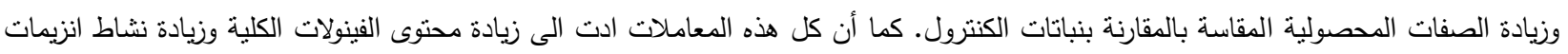
البيروكسيديز , البولى فينول اوكسيديز والثيتينيز بالمقارنة بنباتات الكنترول الغير معاملة. 